\title{
Thermal Analysis of Safety Shoe Toe Cap
}

\author{
Sanjeev Gaur
}

\begin{abstract}
Shoe toe bonnets/caps are the shielding equipment worn in the production company to care for workers' feet from heat. Steel is generally used for safety heavy toe shoe caps that have high thermal conductivity but now the usage of polymer material is growing because of the low pressure \& less thermal conductivity. This study centers on the design \& thermal enquiry of a safety shoe toe bonnet/cap by employing nylon $66 \&$ carbon fiber $(C F)$ in various weight ratios. Safety toe cap design is finished in Siemens NX Uni-graphics subsequently Finite Element Analysis (FEA) employing ANSYS software. ISO 20345: 2011 benchmark is followed for thermal analysis and then compared with steel shoe toe caps. Safety toe cap design is done in Siemens NX Uni-graphics followed by Finite Element Analysis (FEA) using ANSYS software. Comparison with steel shoe toe caps.
\end{abstract} carbon fibre

\section{INTRODUCTION}

Common consumer products using commercially available plastic products like: fishing rods, basketball bats, \& water storage tank, roof tiles \& safety toecaps. Finite element (FE) analysis has traditionally been used as an economical technique for designing \& forecasting product performance underneath different service circumstances [1][3].

The shift from using traditional goods to plastic goods in safety products has now changed to FE modeling approaches for the productive industry. While designing common/general merchandises using composite materials related to advanced FE analytical capabilities may not be necessary, nevertheless companies face difficulties in the design, manufacturing and analysis stages. The main reason remains in the fundamental dissimilarity $b / w$ traditional metal / plastic constructions \& composite materials: traditional materials of isotropic character offer equal strength in all directions; while the strength properties of composite materials are significant. Therefore, the FE analysis calls for changes in the setup of material models \& failure modes [4]-[8].

This research involved a systematic analysis of different product design using composite materials over traditional metallic components, with a safety toecap selected as the target product. In this research, the issues of FE modeling, analysis, optimization \& manufacturing of the development method for common plastic products were investigated. "Safety Toecap" is by definition a protective cover over the toe cap of safety shoes. They are commonly employed as protective components in safety footwear to counteract potential risks to people such as falling objects, side effects, cuts, interruptions, tension and risks other potential exposure to chemical or thermal hazards [9]-[13].

Revised Manuscript Received on September 14, 2019.

Dr. Sanjeev Gaur, Department of Mechanical Engineering, Sanskriti University, UttarPradesh, India. (E-mail: sanpubip@gmail.com)
Keywords: toe caps, polymer, thermal conductivity, nylon 66, \&

While toecaps made of different materials may provide protection against a range of risks, toecaps are mostly made of steel or plastic.

To raise thermal characteristics by employing Carbon Fiber Reinforcement.

Raising the front \& back depth of the thumb cap to increase additional height \& strength [14]-[16].

\section{TYPES OF POLYMER [17]-[20]}

\section{Thermoplastic}

Thermoplastic, or thermo-softening plastic, is a plastic polymer/composite material that turn out to be pliable/moldable at certain high temperatures \& hardens on cooling. Maximum thermoplastics have from top to bottom molecular weight.

\section{MATERIAL USED}

The material used for the fabrication of the toe are:

Carbon Material (with difference percentage)

Polyamide 66 (with difference percentage)

Nylon 66 or Polyamide 66 and polymer reinforced with carbon fiber has good thermal properties toes composite polymer thus making it a better substitute for bulky and expensive steel toe cap at particularly high temperatures and harden on cooling. Most thermoplastics have a high molecular weight [21]-[24].

\section{DESIGN}

The 3-D mode of the toe cap is shown in Figure 1.

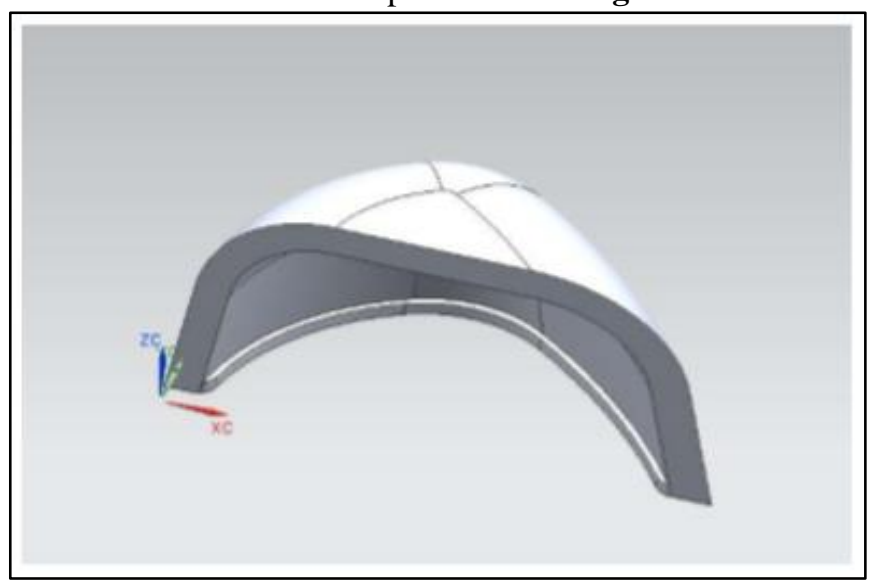

Figure 1. 3D Model of safety shoe toe cap

Analysis

Analysis of the toe cap is done in ANSYS software Simple Toe Cap

Published By: Blue Eyes Intelligence Engineering 
Thermal Analysis Of Safety Shoe Toe Cap

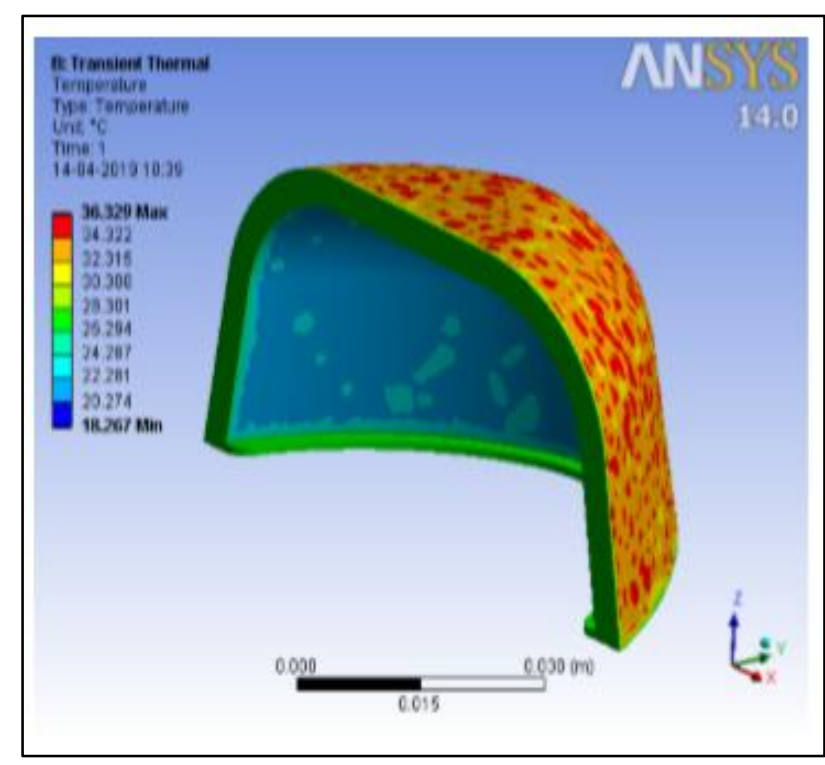

Figure 2. PA 66

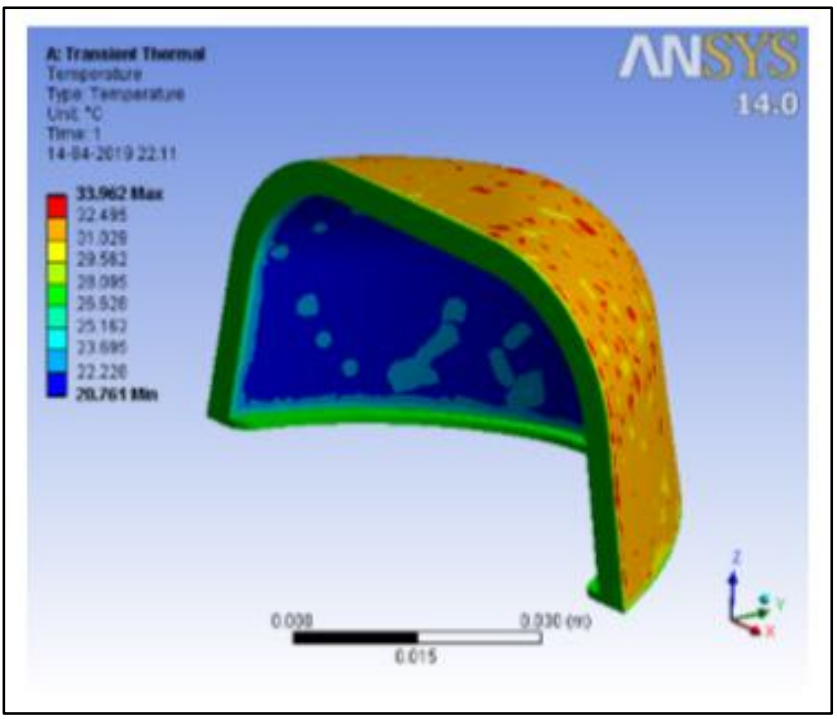

Figure 3. PA66 + 10 CF

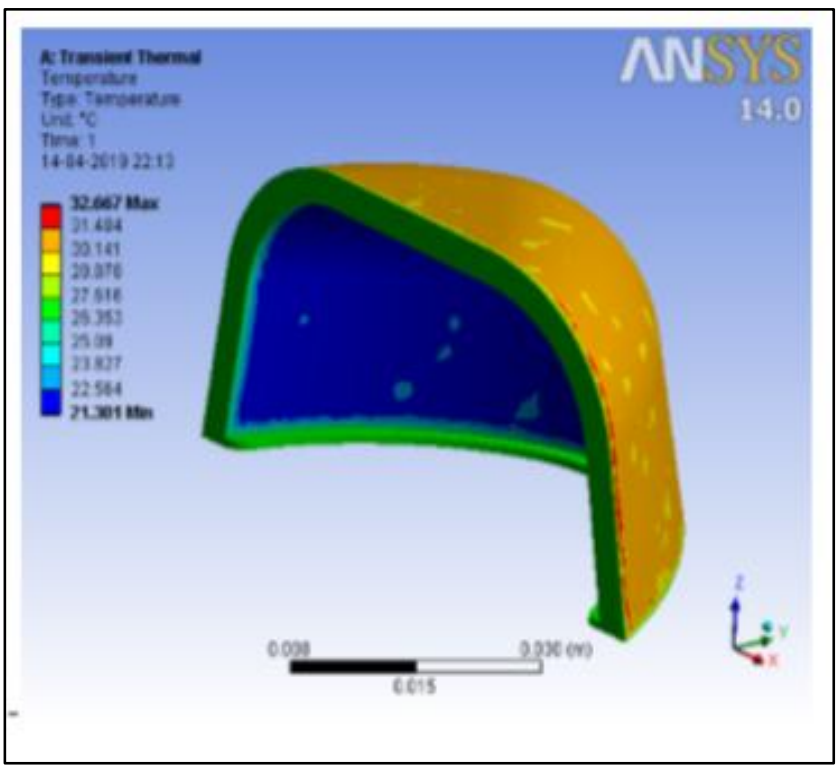

Figure 4. PA66+ 20 CF

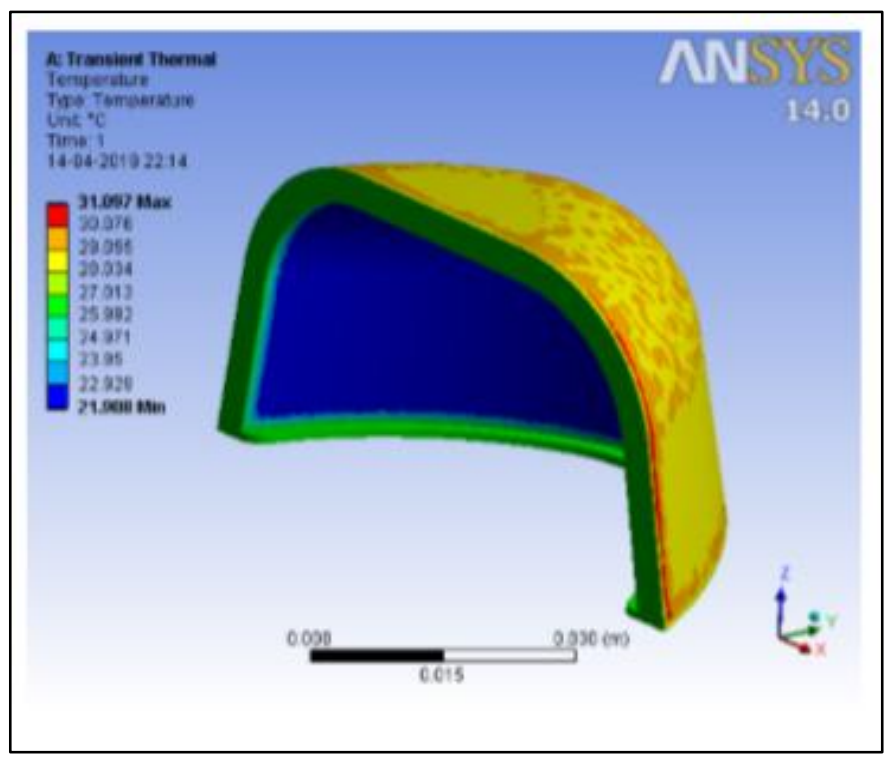

Figure 5. PA66+ $30 \mathrm{CF}$

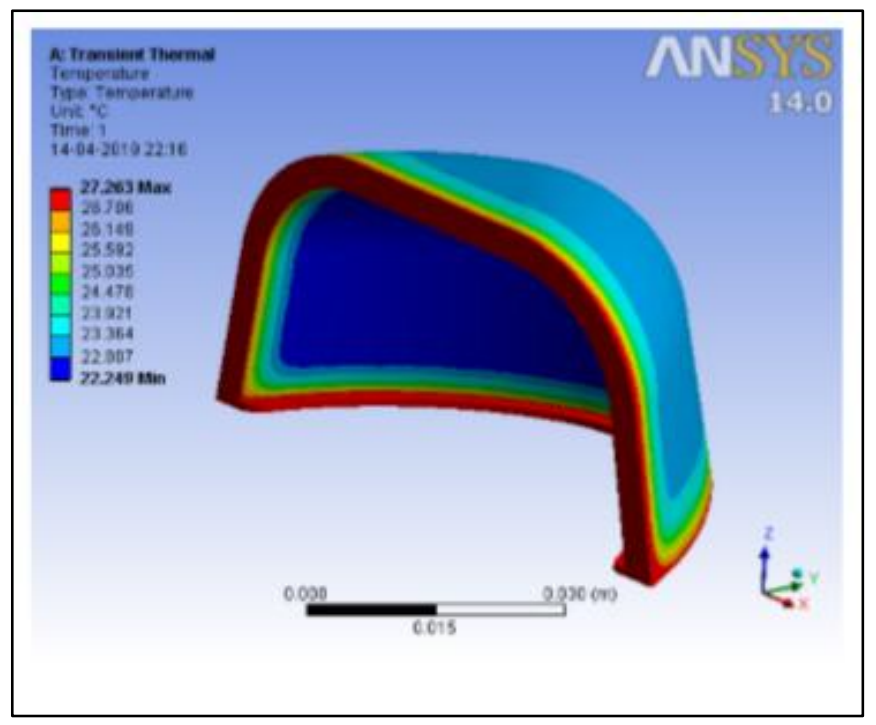

Figure 6. SS

\section{HONEY COMB STRUCTURE OF TOE CAP \& RESULTS}

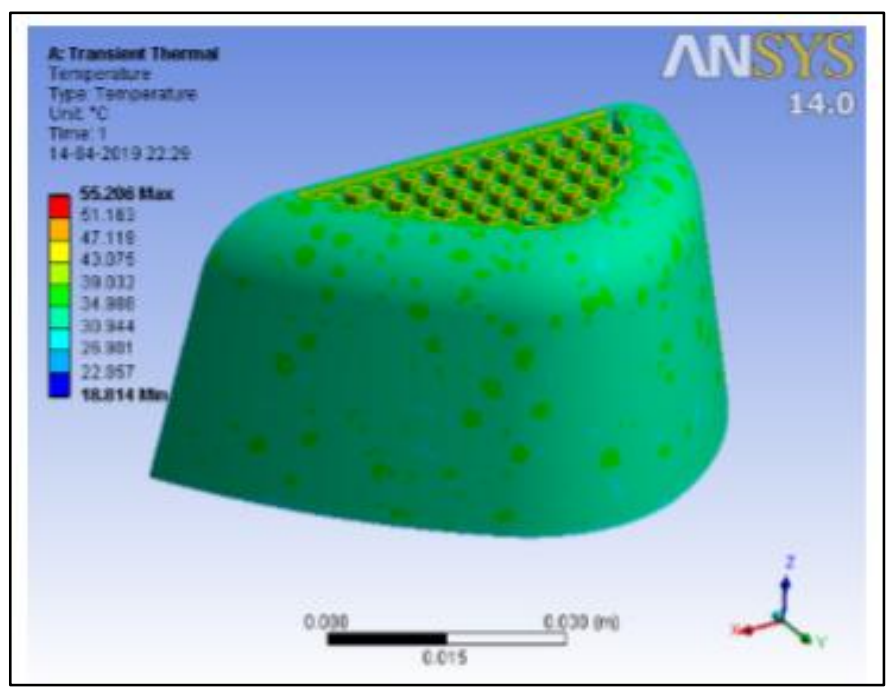

Blue Eyes Intelligence Engineering

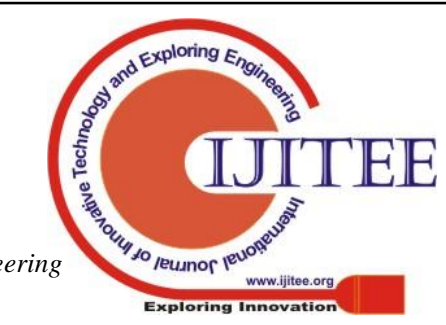




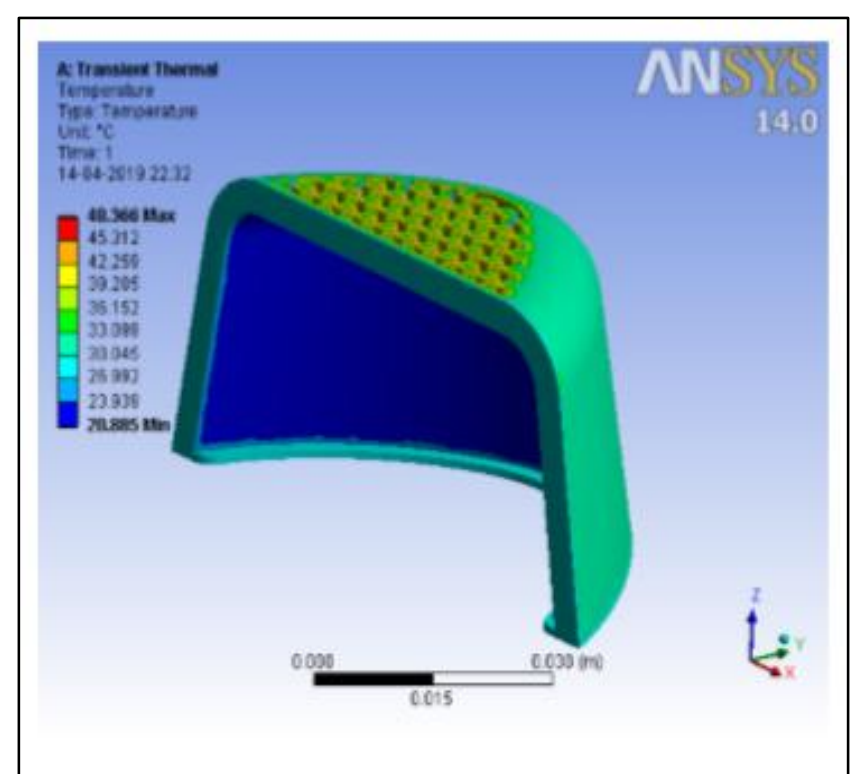

Figure 8. PA66+ 10 CF

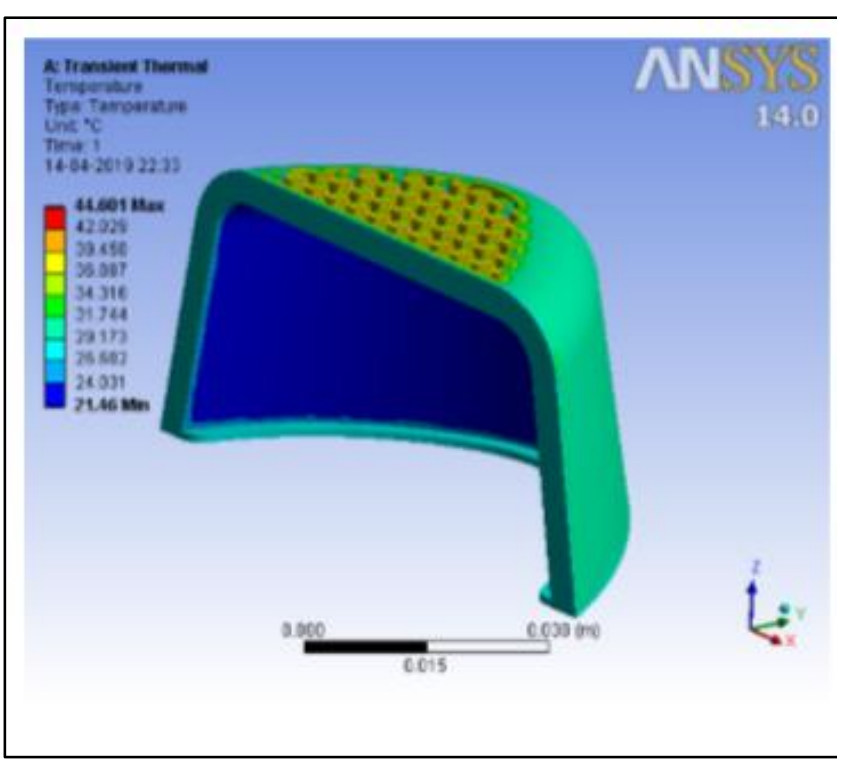

Figure 9. PA 66+30 CF

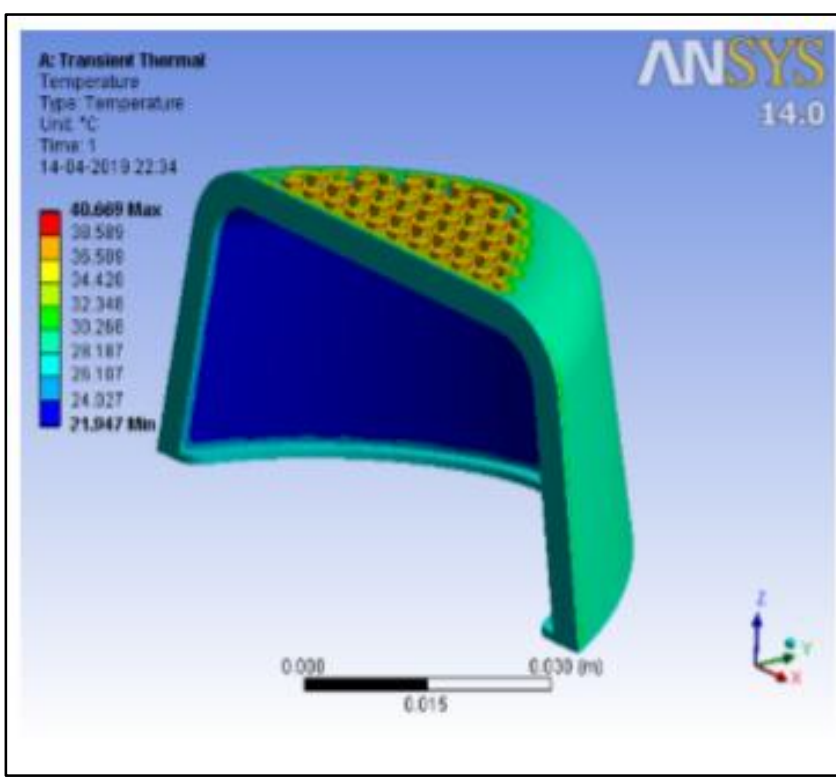

Figure 10. PA66+ 30 CF

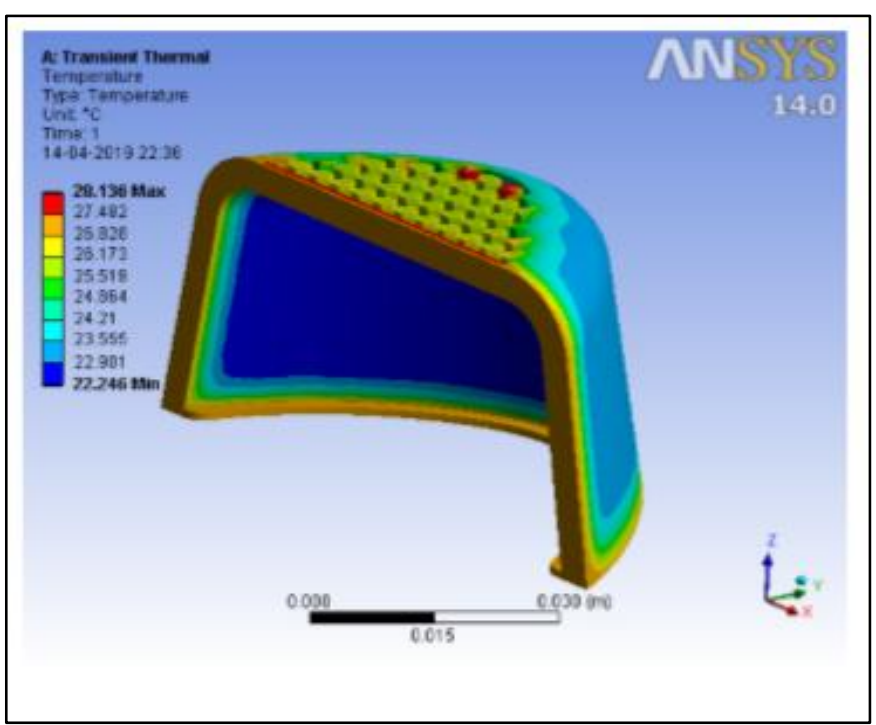

Figure 11. SS

\section{Ribbed Toe Cap}

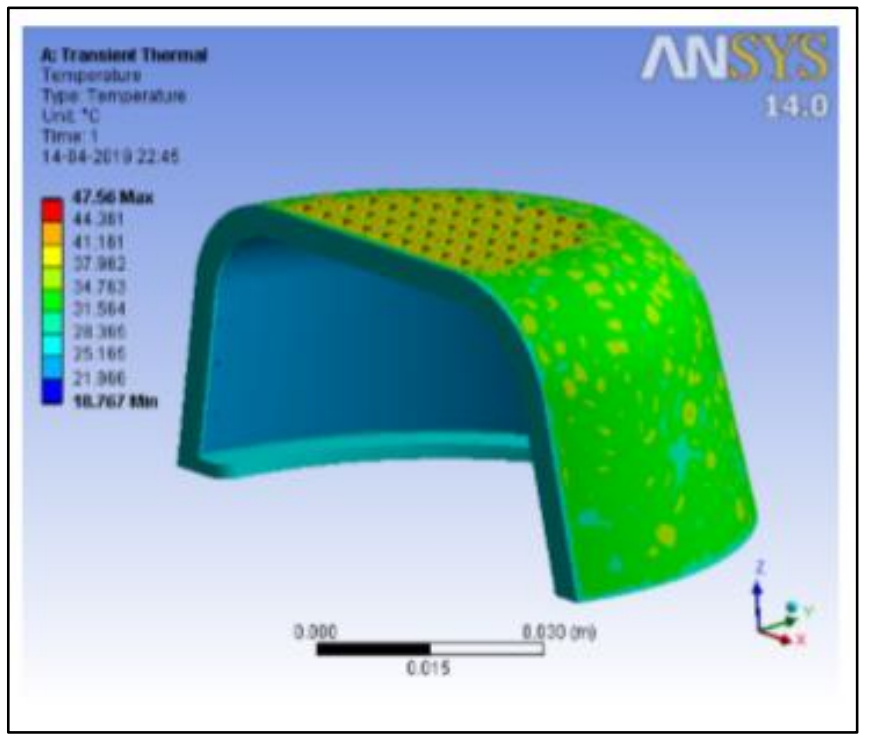

Figure 12. PA 66

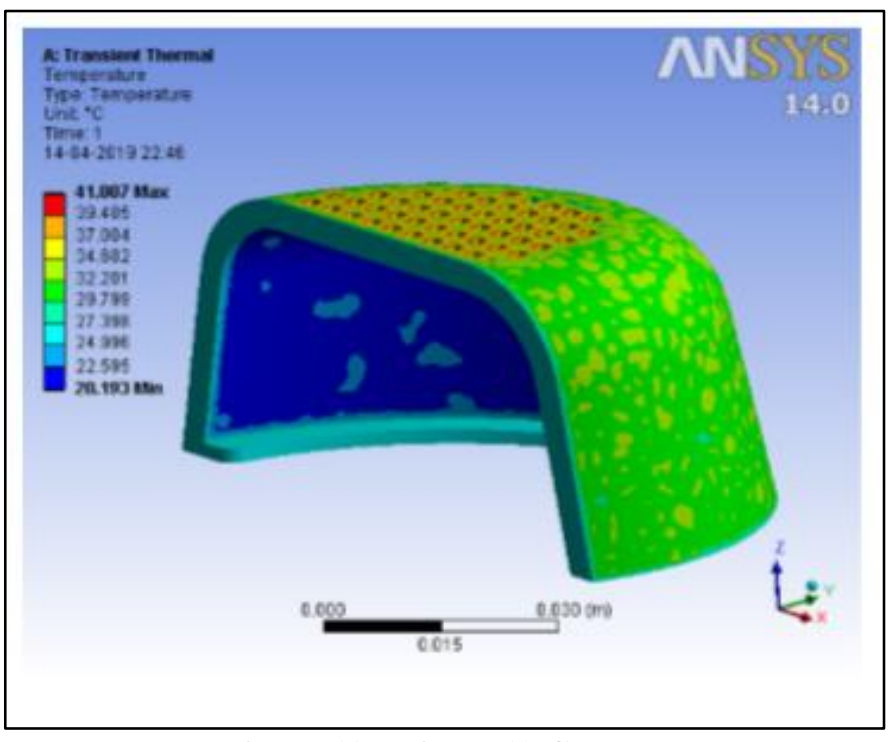

Figure 13. PA66+ 10 CF

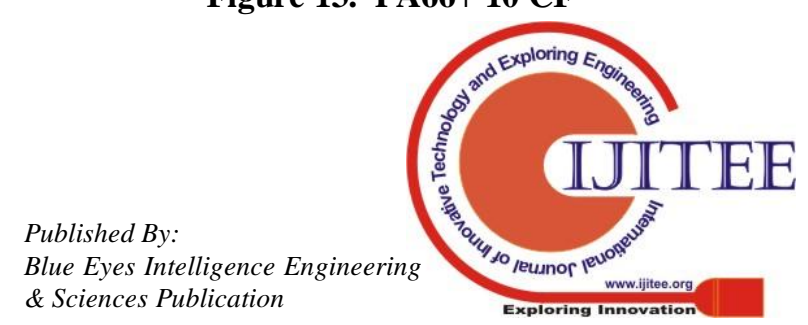




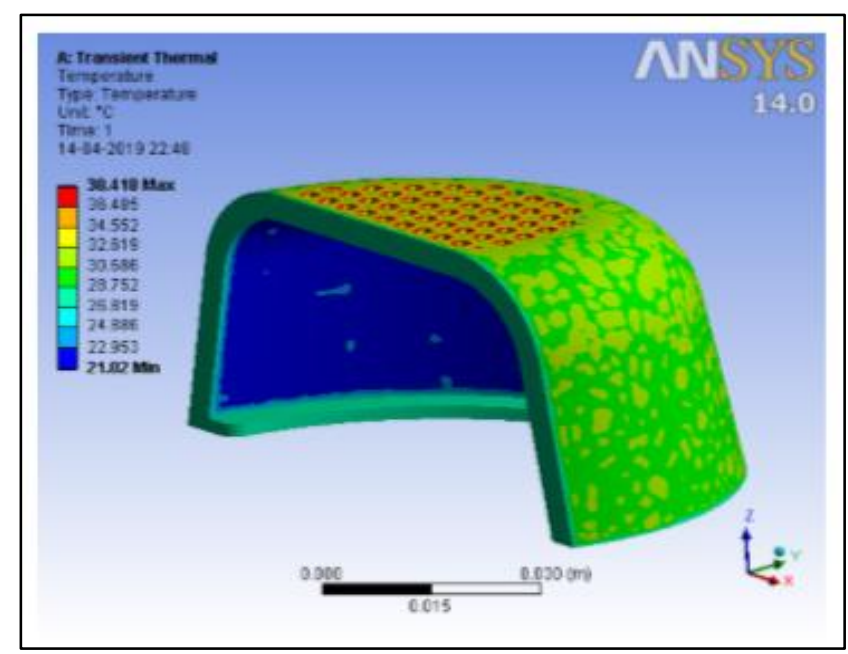

Figure 14. PA66+ 20 CF

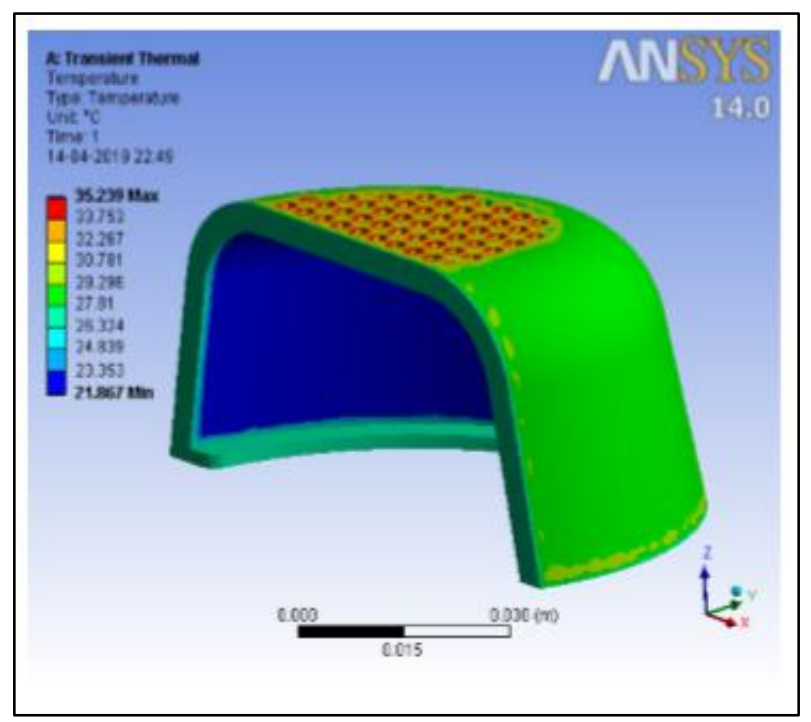

Figure 15. PA66+ 30 CF

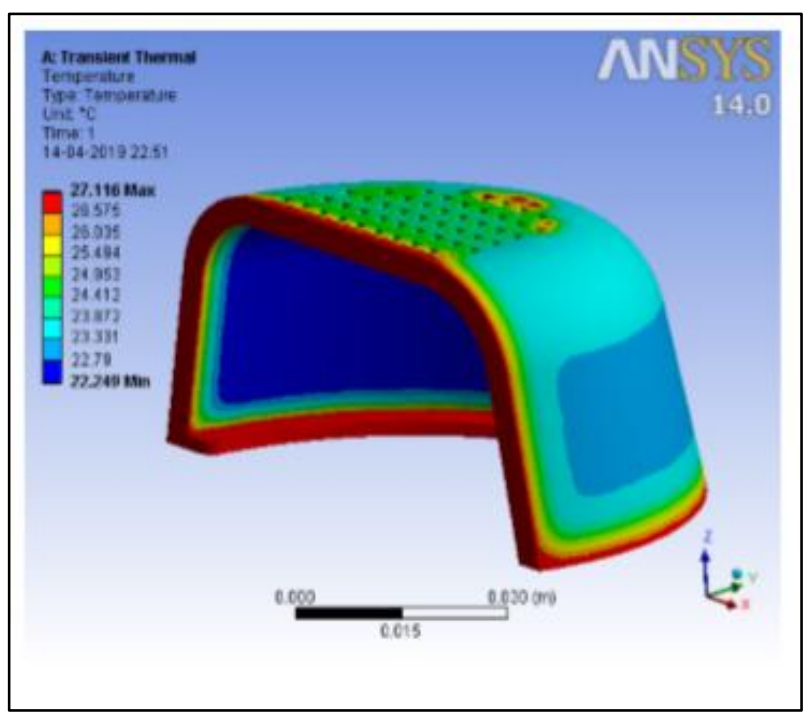

Figure 16. SS

\section{RESULTS}

The analysis results are given in the Figure $\mathbf{1 7}$ there are different design of the Safety Shoe Toe Cap and every model is analysed separately in ANSYS application.

\begin{tabular}{|l|l|l|l|l|l|l|}
\hline & & $\begin{array}{l}\text { PA6 } \\
\mathbf{6}\end{array}$ & $\begin{array}{l}\text { PA66+ } \\
\text { 10CF }\end{array}$ & $\begin{array}{l}\text { PA66+ } \\
\mathbf{2 0 C F}\end{array}$ & $\begin{array}{l}\text { PA66+ } \\
\text { 30CF }\end{array}$ & SS \\
\hline $\begin{array}{l}\text { Simp } \\
\text { le }\end{array}$ & Min & $\begin{array}{l}18.26 \\
7\end{array}$ & 20.761 & 21.301 & 21.308 & 22.249 \\
\cline { 2 - 7 } & Max & $\begin{array}{l}36.32 \\
9\end{array}$ & 33.962 & 32.666 & 31.097 & 27.263 \\
\hline $\begin{array}{l}\text { Hone } \\
\text { ycom } \\
\text { b }\end{array}$ & Min & $\begin{array}{l}18.81 \\
4\end{array}$ & 20.885 & 21.460 & 21.947 & 22.246 \\
\cline { 2 - 7 } & Max & $\begin{array}{l}55.20 \\
6\end{array}$ & 48.366 & 44.601 & 40.669 & 28.136 \\
\hline $\begin{array}{l}\text { Ribb } \\
\text { ed }\end{array}$ & Min & $\begin{array}{l}18.76 \\
7\end{array}$ & 20.193 & 21.02 & 21.867 & 22.249 \\
\cline { 2 - 7 } & Max & $\begin{array}{l}47.56 \\
0\end{array}$ & 41.807 & 38.418 & 35.239 & 27.116 \\
\hline
\end{tabular}

Figure 17. Analysis data result

\section{CONCLUSION}

After the analysis following advantages \& disadvantages can be considered

\section{Advantages}

Decent tensile strength, \& flexural modulus/modulus, \& lateral stability, fracture \& wear characteristics related to basic polyamide 66 plastic, great thermal conductivity value.

\section{Disadvantages}

Molds may have anisotropic characteristics, Poor electrical resistivity with substantial decrease in stretch at rest. Extended equated to unmodified polyamide 66 plastics.

\section{REFERENCE}

1. J. Huang and X. Wang, "On a new crush trigger for energy absorption of composite tubes," Int. J. Crashworthiness, vol. 15, no. 6, pp. 625-634, Dec. 2010

2. M. M. Shokrieh, H. Tozandehjani, and M. J. Omidi, "Effect of fiber orientation and cross section of composite tubes on their energy absorption ability in axial dynamic loading," Mech. Compos. Mater., vol. 45, no. 6, pp. 567-576, Nov. 2009.

3. G. C. Jacob, J. F. Fellers, and J. M. Starbuck, "Energy Absorption in Polymer Composite Materials for Automotive Crashworthiness."

4. N. V Padaki, R. Alagirusamy, L. Deopura, and R. Fangueiro, "Low velocity impact behaviour of textile reinforced composites," 2008.

5. M. A. Shaharuzaman, S. M. Sapuan, M. R. Mansor, and M. Y. M. Zuhri, "PASSENGER CAR'S SIDE DOOR IMPACT BEAM: A REVIEW."

6. D. G. Lee and S. S. Cheon, "Impact Characteristics of Glass Fiber Composites with Respect to Fiber Volume Fraction," J. Compos. Mater., vol. 35, no. 1, pp. 27-56, Jan. 2001.

7. F. Sarasini et al., "Drop-weight impact behaviour of woven hybrid basalt-carbon/epoxy composites," Compos. Part B Eng., vol. 59, pp. 204-220, Mar. 2014.

8. Y. Mi, Q. Yan, X. Li, M. Hong, M. Cao, and X. Zhang, "Effects of temperature induced thermal expansion and oxidation on the Charpy impact property of $\mathrm{C} / \mathrm{C}$ composites," J. Wuhan Univ. Technol. Sci. Ed., vol. 30, no. 3, pp. 473-477, Jun. 2015.

9. M. Zhang, X. Q. Dai, Y. Li, and J. T.-M. Cheung, "Computational Simulation of Skin and Sock Pressure

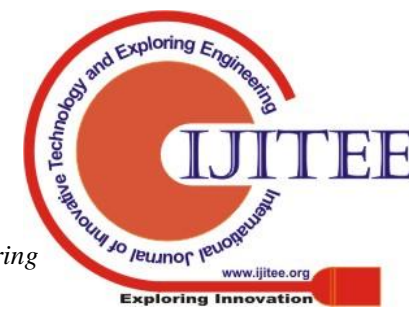


Distributions," Springer, Berlin, Heidelberg, 2007, pp. 323-333.

10. R. L. Actis et al., "Multi-plug insole design to reduce peak plantar pressure on the diabetic foot during walking.," Med. Biol. Eng. Comput., vol. 46, no. 4, pp. 363-71, Apr. 2008.

11. D. J. Lott, M. K. Hastings, P. K. Commean, K. E. Smith, and M. J. Mueller, "Effect of footwear and orthotic devices on stress reduction and soft tissue strain of the neuropathic foot.," Clin. Biomech. (Bristol, Avon), vol. 22, no. 3, pp. 352-9, Mar. 2007.

12. S. Franklin, M. J. Grey, N. Heneghan, L. Bowen, and F. X. Li, "Barefoot vs common footwear: A systematic review of the kinematic, kinetic and muscle activity differences during walking," 2015.

13. "A RESEARCH ON FOOTWEAR AND FOOT INTERACTION THROUGH ANATOMY AND HUMAN ENGINEERING," 2005.

14. E. A. Campo, The complete part design handbook: for injection molding of thermoplastics. Hanser Publishers, 2006.

15. E. A. Campo, The complete part design handbook: for injection molding of thermoplastics. Hanser Publishers, 2006.

16. E. A. Campo, The complete part design handbook: for injection molding of thermoplastics. Hanser Publishers, 2006.

17. S. Telfer, A. Erdemir, J. Woodburn, and P. R. Cavanagh, "What Has Finite Element Analysis Taught Us about Diabetic Foot Disease and Its Management? A Systematic Review," PLoS One, vol. 9, no. 10, p. e109994, Oct. 2014.

18. Y. Roiter and S. Minko, "AFM single molecule experiments at the solid-liquid interface: in situ conformation of adsorbed flexible polyelectrolyte chains.," J. Am. Chem. Soc., vol. 127, no. 45, pp. 15688 9, Nov. 2005.

19. "macromolecule (polymer molecule)," in IUPAC Compendium of Chemical Terminology, Research Triagle Park, NC: IUPAC.

20. W. B. Jensen, "The Origin of the Polymer Concept," $J$. Chem. Educ., vol. 85, no. 5, p. 624, May 2008.

21. "Classification of Polymers: Source, Structure, Polymerisation, Examples." [Online]. Available: https://www.toppr.com/guides/chemistry/polymers/classi fication-of-polymers/. [Accessed: 09-Aug-2019].

22. A. J. Peacock and A. R. Calhoun, Polymer chemistry: properties and applications. Hanser Gardner Publications, 2006.

23. S. Pilla, Handbook of bioplastics \&amp; biocomposites engineering applications. Wiley, 2011.

24. "alternating copolymer," in IUPAC Compendium of Chemical Terminology, vol. 68, no. 12, Research Triagle Park, NC: IUPAC, 1996, pp. 2287-2301. 